\title{
A new approach to conservation: using community empowerment for sustainable well-being
}

\author{
Alaka Wali $^{1}$, Diana Alvira $^{2}, \underline{\text { Paula S. Tallman }}^{2}, \underline{\text { Ashwin Ravikumar }}^{2,3}$ and Miguel O. Macedo $^{4}$
}

\begin{abstract}
The global environmental conservation community recognizes that the participation of local communities is essential for the success of conservation initiatives; however, much work remains to be done on how to integrate conservation and human wellbeing. We propose that an assets-based approach to environmental conservation and human well-being, which is grounded in a biocultural framework, can support sustainable and adaptive management of natural resources by communities in regions adjacent to protected areas. We present evidence from conservation and quality of life initiatives led by the Field Museum of Natural History over the past 17 years in the Peruvian Amazon. Data were derived from asset mapping in 37 communities where rapid inventories were conducted and from 38 communities that participated in longer term quality of life planning. Our main findings are that Amazonian communities have many characteristics, or assets, that recent scholarship has linked to environmental sustainability and good natural resource stewardship, and that quality of life plans that are based on these assets tend to produce priorities that are more consistent with environmental conservation. Importantly, we found that validating social and ecological assets through our approach can contribute to the creation of protected areas and to their long-term management. As strategies to engage local communities in conservation expand, research on how particular methodologies, such as an assets-based approach, is needed to determine how these initiatives can best empower local communities, how they can be improved, and how they can most effectively be linked to broader conservation and development processes.
\end{abstract}

Key Words: Amazon; assets; biocultural; conservation; forest dwellers; indigenous communities; Peru; protected areas management; wellbeing

\section{INTRODUCTION}

Environmental conservation encompasses efforts to manage nature with the aim of protecting Earth's biodiversity from excessive rates of extinction and the erosion of biotic interactions. Until recently, the practice of conservation emphasized creating protection for threatened biodiverse landscapes through categorizations that restrict human use or encroachment in ways that allow other species to thrive. However, in recent decades, the global environmental conservation community has come to appreciate that their initiatives must engage with local people if they are to succeed (Chapin 2004, Cernea and Schmidt-Soltau 2006, West and Brockington 2006, Otto et al. 2013). Further, a growing body of evidence suggests that paying attention to improving local peoples' well-being, particularly in the rural tropics, can enhance environmental sustainability because local communities can and do act as stewards of the natural resources that secure their livelihoods (Cernea and Schmidt-Soltau 2006, Sheil et al. 2006, Colchester 2009). The core issue that remains to be addressed is how policy-makers, nongovernmental organizations (NGOs), and indigenous organizations can best engage local communities in conservation to realize these synergies in ways that benefit both humans and nonhumans in forest ecosystems (Sayer and Campbell 2005).

We suggest that an assets-based approach to environmental conservation and human well-being that operates within a biocultural framework can support sustainable and adaptive management of natural resources by communities in regions adjacent to protected areas. As evidence, we present data from research conducted in the Peruvian Amazon by a team of researchers from the Field Museum of Natural History based in Chicago, Illinois. The Field Museum's team of ecologists and social scientists has been partnering with local conservation organizations in the Peruvian Amazon since 1999 to protect biodiverse landscapes and be more inclusive of local populations in management efforts.

To contextualize these data, we first provide background, definitions, and justifications for an integrated approach to conservation that uses a biocultural approach to human wellbeing. We then describe the Field Museum's particular strategy, an assets-based approach, for linking conservation and wellbeing, and the Amazonian context where it has been deployed. Next, we present results and key findings from the initiatives led by the museum over the past 17 years in 37 communities where rapid inventories were conducted, and from 38 communities that participated in longer term participatory conservation initiatives in different parts of the Peruvian Amazon.

We find evidence that including local perspectives and knowledge of forest biodiversity leads to support for setting aside protected areas. In particular, facilitating critical reflection about livelihood priorities through participatory conservation approaches can effectively align community actions with natural resource management strategies that may improve conservation outcomes. This is because an assets-based approach creates a cycle of empowerment. First, it empowers local people to participate in conservation efforts. Governments are then more likely to respond favorably to community demands. This can then strengthen local peoples' capacity to create sustainable livelihoods and improve well-being. Finally, we provide guidance for further research, which suggests that this work is of critical importance to policymakers as strategies to engage communities in conservation proliferate. We conclude that more research is required to track

\footnotetext{
${ }^{1}$ Integrated Research Center, The Field Museum of Natural History, ${ }^{2}$ Keller Science Action Center, The Field Museum of Natural History,
}

${ }^{3}$ Department of Environmental Studies, Amherst College, ${ }^{4}$ Instituto del Bien Común 
how communities that have developed quality of life plans or similar instruments engage with outside conservation and development opportunities.

\section{Well-being and conservation: definitions and measurement} To understand why consideration of the well-being of people living in biodiverse ecosystems is significant for improving conservation outcomes, we must first expand the definition of well-being to be sensitive to local contexts.

There is a broad consensus that measurements of well-being must go beyond the traditional economic indices of gross domestic product and per capita income. Stiglitz et al. (2010) documented in their ground-breaking work that these indices are inadequate to account for the interrelated components that determine true well-being. They focused on including measurements of health and educational outcomes, and access to political participation among other variables, with an eye to the distribution of resources rather than mere accumulation and growth of wealth. This more multidimensional approach to measuring well-being is gaining wider acceptance in the conservation community because it offers the potential to show how highly intense, extractive-dependent growth strategies are not the only way for nations with high biodiversity to address the needs of their citizens. This body of work emphasizes quantifiable indicators of nonmonetary aspects of well-being, and the distribution of wealth.

Going further, a growing literature on well-being has emphasized the need for context-specific indicators of well-being for diverse peoples (Dodge et al. 2012, La Placa et al. 2013, Leisher et al. 2013). Sometimes called the "biocultural" approach (Sterling et al. in press), this work emphasizes a more fine-grained analysis of the characteristics of well-being as defined by people in different environments. It attempts to grapple with how the variety of local experiences can be generalized into indicators that simultaneously can be generally applied but are context-sensitive. Our work builds upon this view.

How can different perceptions and values about what constitutes good health or education or sound infrastructure be measured on their own terms? Asking this question allows us to consider the distinct cultural practices and beliefs of forest dwellers who maintain a subsistence-oriented livelihood. For them, well-being is measured in a more integrated way that places economic satisfaction within a broader context of social experience and their natural surroundings (Wali 2012). Among forest-dwellers in Amazonia, in particular, well-being includes assessment of the balance between humans, other life forms, and supernatural beings, and a moral dimension that regulates relationships, especially across generations (Viveiros de Castro 1998, Chirif 2007, del Campo and Wali 2007, Belaunde 2010, de la Cadena 2010). For example, despite the massive displacements and upheavals resulting from encounters with European colonizers and settlers, indigenous peoples have retained continuities with practices that were created to sustain a livelihood in the fragile Amazonian ecosystem. Such continuities encompass knowledge of ecological processes and relations, natural resource use strategies, social practices of resource sharing, and forms of labor organization based in a kinship mode of production (Wolf 1982). These cultural practices and belief systems, in turn, have been associated with zones of high biodiversity, as demonstrated in the mapping work of Chapin et al. (2005), Maffi (2001), and Stepp et al. (2004). Further scholarship on common pool resource management suggests that when local people are empowered to manage their lands autonomously, they do so in ways that are consistent with environmental sustainability (Agrawal 2001, Agrawal and Chhatre 2006, Ostrom 2015).

We contend that to the extent that these continuities govern social life and buffer against market-driven practices that intensify extraction of natural resources, they enable Amazonian peoples to define well-being for themselves in secure and sustainable forms and enable them to more confidently participate in conservation of their biodiverse ecosystem. On the flip side, pervasive drivers of environmental degradation, such as extractive enterprises and industrial-scale agriculture, can threaten local peoples' livelihoods and erode social assets and local cultural norms over time. In the following section, we discuss how we developed an assessment approach that focuses on identifying the assemblage of distinct practices and beliefs (which we call social assets) that are the foundation for well-being and that can serve as the basis for engaging communities in effective conservation management in the Amazonian context.

\section{METHODS}

\section{Sites and data sources}

The Field Museum of Natural History in Chicago, Illinois has engaged in conservation efforts in the Andes-Amazon region through two programmatic efforts: rapid inventories in 23 sites in Peru, Ecuador, Bolivia, and Colombia (The Field Museum $2016 a$ ), and longer term participatory conservation interventions in watersheds that are associated with three protected areas in Peru (The Field Museum 2016b). Rapid inventories are expert surveys of the geology and biodiversity of remote forests, paired with social assessments that identify natural resource use, social organization, cultural strengths, and the aspirations of local residents (The Field Museum 2011). The objective is to provide strong scientific information and integrated recommendations to protect the landscape and strategies for engaging local populations living adjacent to the area. The rapid inventory team selects sites for inventories through a careful process of examining satellite images and current land use maps, conducting overflights, and discussing conservation opportunities and threats with experienced local partners. Once these data are collected, researchers, indigenous organizations, and environmental nonprofits use them to make recommendations for conservation and advocate for protected areas management strategies that involve local people. The data are also shared among local stakeholders to build a shared vision for the landscapes, and to develop political coalitions that go on to advocate for responsible protection and management. Overall, these rapid inventories have contributed to placing a total of 32 million acres (13 million hectares) of forest into protected area status in the AndesAmazon region (Fig. 1) (The Field Museum 2011).

To select communities for the social assessment, we examine demographic data and feasibility of access, and work closely with indigenous federations and small-farmer organizations and leaders to orchestrate the fieldwork. Communities are comprised largely of indigenous and long-term traditional forest dwellers, and community sizes range from approximately 100 to 1000 people. These communities are located in remote areas within immense tracts of healthy forest ecosystems. 
Fig. 1. Rapid inventory sites, established protected areas, and proposed protected areas.

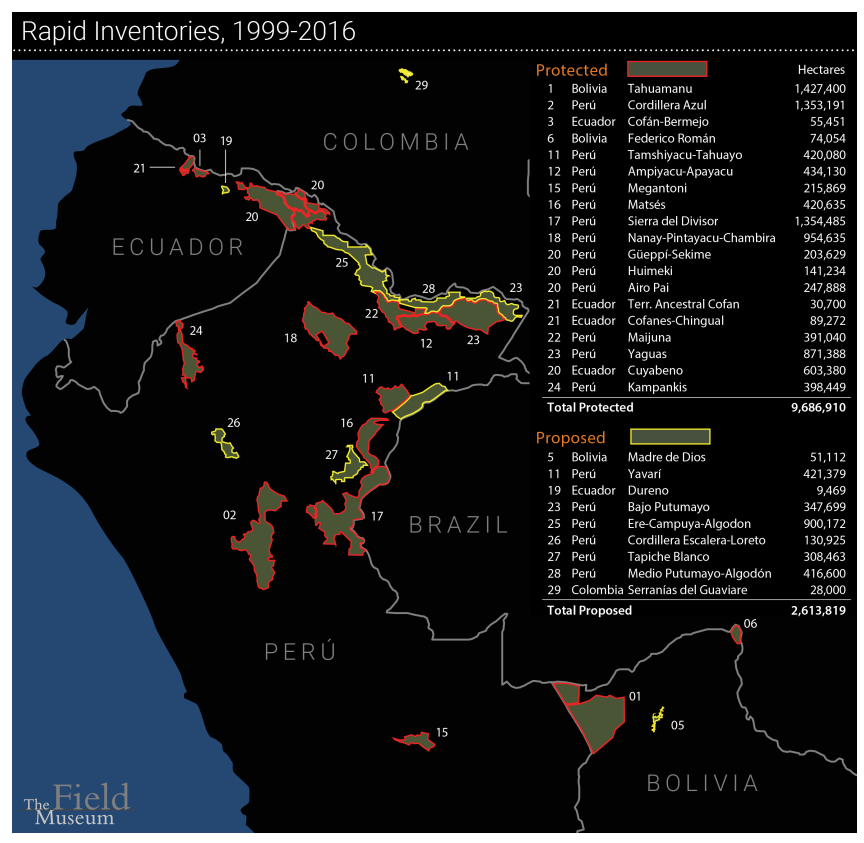

The data we present were derived from six rapid social inventories conducted in the Department of Loreto in the Peruvian Amazon: (1) Güeppí (Alverson et al. 2008), (2) the Yaguas-Cotuhé and Putumayo watersheds (Pitman et al. 2011), (3) the Ere-CampuyaAlgodón watershed (Pitman et al. 2013), (4) the sub-Andean mountain range of the Cordillera Escalera-Loreto (Pitman et al. 2014), (5) the Tapiche-Blanco watershed (Pitman et al. 2015), and (6) the Medio Putumayo-Algodón watersheds (Pitman et al. 2016) (Fig. 2). A total of 37 communities at these six sites participated in the inventories. We focus on these six areas because they constitute a largely contiguous area of healthy forest where we and our Peruvian partners have been successful in initiating protection efforts.

Additionally, we used data from longer term participatory conservation efforts in the Peruvian Amazon that involved 38 communities in the buffer zones of the Cordillera Azul National Park (2009-2011), the Ampiyacu-Apayacu Regional Conservation Area (2011-2014), and the Sierra del Divisor National Park (2011-2014). In these three areas, where rapid inventories had contributed to the creation of a protected area, we extended community engagement as part of the effort to guide actual management of the area and its associated buffer zone. Fig. 2 shows the research sites.

In all three zones, we developed community "quality of life plans" based on residents' aspirations for improving well-being and which were linked to better management of natural resources. Quality of life planning processes are gaining traction across Amazonia and are conducted in a variety of formats. Generally, the aim is to enable communities to better address their needs while respecting their cultural values and beliefs (Velásquez Landmann and Macedo Bravo 2016).
Fig. 2. Research sites from rapid inventories and longer term participatory conservation initiatives in the Peruvian Amazon.

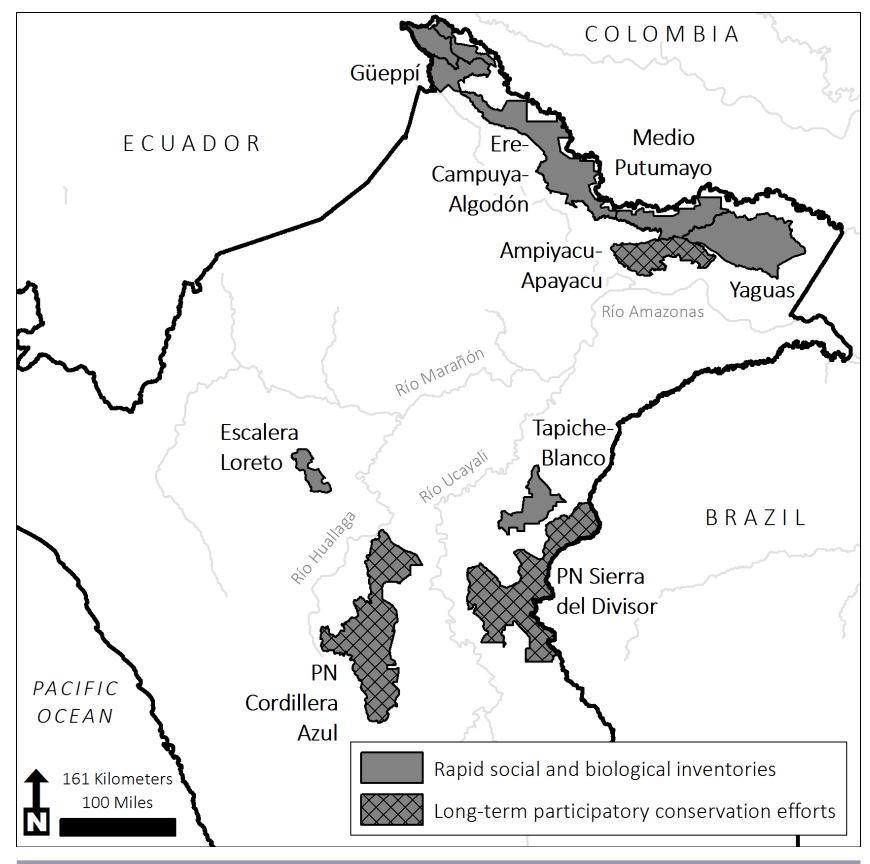

It is worth emphasizing that this study is the result of a long-term action research program. The main priority of the project implementers was to ensure that all the instruments and tools we describe were deployed in a manner that was appropriate for local conditions. These instruments can be found (in Spanish) at the Field Museum (date unknown $a$ ). At the same time, the tools were continually improved over the course of this project to elicit information more efficiently and to serve the needs of communities and partner organizations. While we designed the tools to be flexible and adaptable to diverse social, economic, and ecological contexts, the underlying theory is consistent, and the information gathered is amenable to comparison and analysis. In all cases, we used ethnographic techniques to catalogue local knowledge, history, and values. We consistently deployed participatory mapping to determine where and how natural resources were accessed, used, and managed. We ascertained how communities were organized politically to make decisions - both in terms of their formal organization, and in practice - and to coordinate shared labor through ethnography, surveys, and focus groups. And we used household surveys and focus groups to characterize local livelihood strategies. While some of these tools evolved over time and have been modified for local contexts, their current iteration reflects our approach accurately, and this central approach has remained consistent in this project.

\section{Research techniques}

The assessment of social assets ("asset mapping") is the principal technique we used to determine the degree of retention of cultural practices and beliefs that define the distinct Amazonian lifestyle in both rapid inventories and longer term participatory conservation initiatives. Social assets are the local capacities and ecological expertise that can empower communities to sustain a 
good quality of life and steward the management of their natural resources and cultural practices. Asset mapping is adapted from urban planners (McKnight and Kretzmann 1993) and has been used in the Field Museum's work in an urban setting within Chicago's Calumet region (Wali et al. 2003). It combines different existing diagnostic instruments, such as ethno-cartography using both sketch maps and satellite images, and participatory rapid appraisal (Chambers 1994, Chapin and Threlkeld 2001, del Campo and Wali 2007) to provide a comprehensive place-based assessment that integrates the identification of ecological knowledge, forms of social organization, and local institutional capacities (Wali 2016).

The specific techniques used to elicit data about social assets are community meetings, focus groups, household surveys, storytelling through photography, resource use, and territory mapping (del Campo and Wali 2007). The goal is to elicit as many community perspectives as possible, and represent the totality of different groups within the community (including gendered groupings, and groupings based primary on livelihoods activities). We determine what groups of people are critical to work with through an initial community assembly. We also use an interactive group exercise in which residents quantify their perceptions of their quality of life in five different dimensions: (1) the state of natural resources, (2) cultural practices and beliefs, (3) social relationships, (4) political life, and (5) the economic situation. Participants are asked to consider the best-case scenario ( 5 on the scale) and the worst-case scenario (1 on the scale) and then rank each dimension on that scale. After all the dimensions are ranked, the facilitator leads a conversation on the interrelationship between the dimensions and how strengths in one area could help overcome weaknesses in another. This exercise spurs discussion regarding the relationship between the environment and quality of life (see Wali et al. 2008 for more details).

These techniques include highly visual and interactive participatory activities that highlight community capacities and strengths. For example, during community meetings, we invite participants to create a community shield or crest with symbols that represent the values of the community members and are emblematic of local identity. The crests enable residents to represent what they are most proud of, and to identify core values and principles. By encouraging community members to explicitly articulate local principles that are central to their identities, the crest serves as a benchmark to assess the degree to which different land use and development options are compatible with who they are and what they want to conserve.

Similarly, participants produce maps of natural and cultural resources on the landscape surrounding their communities that demonstrate the depth of ecological knowledge and the interrelationship of belief and natural resource management. In particular, we highlight how communities regulate the use of natural resources, and document different management strategies that they employ, such as harvest limits, hunting and fishing seasons, or not exploiting certain ecologically or culturally sensitive areas. By explicitly identifying natural resource assets and inventorying local knowledge of how to use them, these maps help communities better plan how to manage natural resource assets under changing conditions.

Household economic surveys provide data on sources of income, types of expenditures, and the balance between subsistence- oriented activities and engagement with the market-driven economy. These surveys are conducted in small group sessions where participants collectively discuss their use of natural resources and fill out illustrated templates.

Asset mapping participants also produce diagrams of kinship networks and the relationships between local and external institutions. Documenting these relationships can be critical in deciding which community members might work together most effectively in implementing a local natural resource management strategy or managing a business. In particular, we document how communities work together to share labor and resources, and what type of interdependent relationships exist in communities.

Finally, we document the organizational structure of the community, and examine the nature of the communities' relationships with external actors such as government offices, NGOs, private firms, and other communities. Understanding these relationships is crucial for future planning and for identifying potential allies to implement key local priorities. Results are ultimately returned to the communities in follow-up workshops, and data are available to others upon request.

The rapid inventories involve only this level of asset mapping, which is used to incorporate recommendations for the shape of the area, plus how to address threats and a strategy for community participation in management. In the longer term participatory conservation efforts, we go further by working with our local partners to deepen community participation in the stewardship of the protected area and in better management of natural resources in their own territories. The main strategy we use is to develop community-based quality of life plans. The main objective of these plans is to help communities delineate timely, measurable activities that improve quality of life, defined with respect to locally specific values and practices. Ultimately, the larger goal is to link these plans to local and regional plans and revenue streams to enable achievement of community objectives and sustainable resource management.

The asset mapping is the first step in the planning process. Other activities for developing the plan include (1) reflection on the identified assets to determine how best to leverage them, (2) consideration of challenges, and most critically, (3) determination of the priorities for communal action. This last activity involves considerable discussion about the trade-offs between a suite of potential initiatives that might include improving infrastructure (e.g., installing potable water or electricity generation), revitalizing cultural practices through bilingual education or other means, generating more income for families, and creating stronger vigilance mechanisms to protect forests and rivers. For each priority, community members think through impact, urgency, required alliances, social assets that might be leveraged to implement the priority, responsible parties, management, potential challenges, and trade-offs. These strategies for execution depend on a commitment by community members to follow through with their self-determined obligations and responsibilities.

\section{Collaboration and information-sharing}

This action research program has been highly collaborative, in that local people carried out much of the research themselves with training and supervision from the Field Museum and partner organizations. Community members who worked with the research team directly were compensated for their time based on 
prevailing local day wage rates. All these collaborative efforts began with requests from communities themselves, or their representative federations, to support establishing protected areas or improving their quality of life in coordination with conservation initiatives. Thus, communities were generally committed to participating in the process, and ultimately saw long-term benefits in terms of shoring up their land rights, natural resource base, and cultural traditions by participating in these processes.

Information from the inventories was always returned to communities and community leaders in follow-up workshops, and longer term engagement with communities was built into the quality of life plans. Over the course of this work, 27 plans have been left with communities to date, and we draw on experiences in these communities for this research. In addition, key parts of the inventory reports were translated into local indigenous languages. The diagnostic information collected from communities was built into the quality of life plans that remained with the communities as official documents that were approved by community consensus.

\section{RESULTS}

\section{Findings from rapid inventory asset mapping}

A large body of scholarship has shown that many factors influence how communities sustainably use resources and that natural resource governance outcomes vary greatly across socialecological systems (Schlager and Ostrom 1992, Ostrom et al. 1999, Dietz et al. 2003, Agrawal and Chhatre 2006, Ostrom 2015). Synthesizing many of the findings of previous decades, Agrawal (2001) suggested that four categories of characteristics most shape outcomes in the local governance of natural resources: (1) resource system characteristics such as size and boundary definitions; (2) human group characteristics, including population size, shared norms and values, leadership, and interdependence among group members; (3) institutional arrangements such as clarity and enforceability of rules, local legitimacy of norms, and accountability of monitors and other officials; and (4) external environment, including technology and the role of the state in supporting rather than undermining local governance arrangements. This typology is useful for assessing how likely communities are to effectively steward natural resources. Our asset mapping work in different parts of the Peruvian Amazon shows that Amazonian communities we have worked with have many characteristics that are known to predict good local governance according to Agrawal's typology and hence contribute to positive conservation outcomes.

Table 1 outlines these characteristics for the communities in each rapid inventory, and highlights conditions relevant to environmental outcomes and showcases the diversity of the inventoried communities. In addition to the information presented in the table, all regions have low population densities, which facilitates sustainable natural resource management irrespective of other conditions.

As outlined in Table 1, in the Field Museum's rapid social inventories, asset mapping revealed the critical characteristics needed for successful participation in conservation efforts. In general, the resource systems we studied involved large intact forests, rivers and oxbow lakes with diverse fish populations, and in some regions, low human population densities. Small-scale shifting cultivation of banana and cassava were found universally, although some communities cultivated a greater diversity of cassava varieties. Managed secondary forests and agroforests were part of these shifting cultivation systems, and a few communities were engaged in low-intensity timber production. Household surveys revealed that while there was steady participation in market-driven activities (including, for example, sale of timber, periodic wage labor, sale of fish), the majority of livelihood depended on subsistence activities, which provided approximately $80-90 \%$ of household needs.

In terms of human group characteristics, in addition to small population density in most of the study areas, community members universally demonstrated extensive ecological knowledge during the natural resource use sketch mapping exercise. For example, participants in the Yaguas-Cotuhé and EreCampuya Algodón social inventories mapped salt licks, lakes, farm plots, and sites of mythical importance, as well as places where timber, plant fibers, medicinal plants, and fruits were harvested. During the mapping process, participants provided a detailed analysis of the spatial patterns of natural resource use and management, such as initiatives to patrol salt licks and monitor palms whose leaves are valued as roof thatch. This degree of ecological knowledge facilitated the development of shared norms of resource use. Although not always codified in statutes, such norms were verbally expressed and easily surfaced in group exercises. Other characteristics included a strong retention of indigenous language in almost all of the indigenous communities, presence of traditional healers and herbalists, and recognition of indigeneity as a unifying force. Among nonindigenous communities, there was an expressed sense of affiliation with a rural or Amazonian identity marked by pride in knowledge of the local environment, shared social norms of behavior, and respect for village authorities.

With respect to institutional arrangements, residents mentioned community agreements that regulate the harvesting of resources such as timber, bushmeat, and fish. For example, participants in the Medio Putumayo-Algodón inventory highlighted the importance of intercommunity collaboration to manage fish populations. Other institutional arrangements that favor sustainable natural resource management are rooted in longstanding local beliefs and traditions that have been transmitted among indigenous communities over generations through myths and taboos.

These types of beliefs surfaced in the resource use mapping in every community included in this data set. For example, the Shawi, who live in the Cordillera Escalera, believe in the power of a'shins (mothers) - spirits that protect certain aspects of the natural world. One of the most important a'shin is the entity Amana, the owner of the forest (Gow 1991). As in other lowland indigenous communities, individuals must negotiate with these spirits in order to harvest natural resources and game animals (Alvira et al.2014). In the Ere-Campuya-Algodón and Medio Putumayo-Algodón inventories, residents explained their belief that some lakes are protected by spirits in the form of enormous anacondas or black pumas that discourage fishers from visiting those lakes frequently (Selaya et al. 2013, Alvira et al. 2016). Similarly, in the TapicheBlanco inventory, participants identified lakes and streams that 
Table 1. Characteristics of communities in each watershed that are associated with sustainable natural resource management.

\begin{tabular}{|c|c|c|c|c|}
\hline $\begin{array}{l}\text { Inventory landscape or } \\
\text { region }\end{array}$ & $\begin{array}{l}\text { Resource system } \\
\text { characteristics }\end{array}$ & Human group characteristics & Institutional arrangements & External environment \\
\hline $\begin{array}{l}\text { Putumayo river basin: } \\
\text { Gueppi-Cuyabeno ( } 14 \\
\text { communities), Medio } \\
\text { Putumayo-Algodón ( } 7 \\
\text { communities), } \\
\text { Ere-Campuya-Algodón } \\
\text { (6 communities), and } \\
\text { Yaguas-Cotuhé ( } 3 \\
\text { communities) }\end{array}$ & $\begin{array}{l}\text { Largely intact forests with } \\
\text { high biodiversity. } \\
\text { Small (<1 ha) farms that } \\
\text { produce mainly cassava and } \\
\text { banana. } \\
\text { Managed secondary forests } \\
\text { that produce timber, } \\
\text { firewood, fruit, and } \\
\text { nontimber forest products. }\end{array}$ & $\begin{array}{l}\text { Ethnically diverse with } 11 \text { groups } \\
\text { but with a strong shared cultural } \\
\text { history (exploitation during the } \\
\text { rubber boom in the early } 19 \text { th } \\
\text { century that led to displacement). } \\
\text { Very low population density; } \\
\text { people concentrated in two major } \\
\text { towns. } \\
\text { Livelihoods based on subsistence } \\
\text { agriculture, commercial and } \\
\text { subsistence fishing, and limited } \\
\text { timber extraction. } \\
\text { Settlement pattern with nucleated } \\
\text { villages of varied size. }\end{array}$ & $\begin{array}{l}\text { Formal land titles for all but two } \\
\text { communities which are in the } \\
\text { process of securing a title. } \\
\text { Informal agreements among } \\
\text { communities in both. Peru and } \\
\text { Colombia to share land and } \\
\text { resources, particularly when there } \\
\text { are floods. } \\
\text { People are organized } \\
\text { geographically in three } \\
\text { indigenous federations with } \\
\text { traditional leadership in place to } \\
\text { a degree. }\end{array}$ & $\begin{array}{l}\text { Strong collaborations with } \\
\text { two local environmental } \\
\text { NGOs and the Peruvian } \\
\text { government around fisheries } \\
\text { management, agroforestry } \\
\text { systems, and forestry. }\end{array}$ \\
\hline $\begin{array}{l}\text { Tapiche Blanco ( } 4 \\
\text { communities) }\end{array}$ & $\begin{array}{l}\text { A mosaic of healthy wetlands, } \\
\text { the largest patch of white- } \\
\text { sand forest in Peru and } \\
\text { upland forest. }\end{array}$ & $\begin{array}{l}\text { The region forms part of the } \\
\text { ancestral territory of the } \\
\text { Capanahua, who shared these } \\
\text { territories with Remo and Matsés } \\
\text { indigenous groups. Migratory } \\
\text { movements were spurred by the } \\
\text { rubber boom in the 19th century. } \\
\text { Very low population densities; } \\
\text { people concentrated in two major } \\
\text { towns. }\end{array}$ & $\begin{array}{l}\text { Only four communities are titled; } \\
\text { the rest are currently seeking } \\
\text { official recognition and land } \\
\text { titles. } \\
\text { All communities are organized as } \\
\text { mixed indigenous and small- } \\
\text { farmer associations to defend the } \\
\text { interests of communities in both } \\
\text { river basins. } \\
\text { Assemblies are increasingly used } \\
\text { as spaces to develop informal and } \\
\text { formal agreements for communal } \\
\text { work and natural resource } \\
\text { management. }\end{array}$ & $\begin{array}{l}\text { Strong collaborations with } \\
\text { local environmental NGO } \\
\text { around land titling, } \\
\text { ornamental fisheries } \\
\text { management, and } \\
\text { community forestry, and } \\
\text { with the National Park } \\
\text { Service (SERNANP). }\end{array}$ \\
\hline $\begin{array}{l}\text { Cordillera Escalera, } \\
\text { Loreto }\end{array}$ & $\begin{array}{l}\text { Megadiverse forests such as } \\
\text { dwarf ridgecrest forest } \\
\text { growing on nutrient-poor } \\
\text { sandstone rock formations at } \\
\text { the highest elevations. } \\
\text { Expanses of tall slope forest } \\
\text { on relatively fertile soils at } \\
\text { middle elevations ( } 800-1200 \\
\text { m), and lowland Amazonian } \\
\text { forest. }\end{array}$ & $\begin{array}{l}\text { Three indigenous groups, the } \\
\text { Shawi, Awajun, and Quechua } \\
\text { Lamista, reside here, and have an } \\
\text { approximate population of } \\
20,000 \text { people. Very low } \\
\text { population densities. } \\
\text { Livelihoods based on subsistence } \\
\text { and small-scale commercial } \\
\text { agriculture, hunting, fishing, } \\
\text { poultry farming, and, since the } \\
\text { 1980s, cattle ranching. } \\
\text { Settlements are dispersed in } \\
\text { numerous villages of variable size } \\
\text { with extensive networks of trails, } \\
\text { campsites, and roads. }\end{array}$ & $\begin{array}{l}\text { Most communities are titled, } \\
\text { although there is an incomplete } \\
\text { and in some cases erroneous land } \\
\text { titling process. } \\
\text { Strong family networks support } \\
\text { natural resource and labor } \\
\text { sharing. } \\
\text { Political organization is strong, } \\
\text { with community governments } \\
\text { and indigenous federations } \\
\text { working together. }\end{array}$ & $\begin{array}{l}\text { Weak collaborations with an } \\
\text { environmental NGO and } \\
\text { with local and regional } \\
\text { government regarding the } \\
\text { protection of Cordillera } \\
\text { Escalera. }\end{array}$ \\
\hline
\end{tabular}

are protected by giant anacondas. In each of these cases, shared beliefs in the presence of mythological beings encourage people to avoid excessive hunting and fishing and thus overharvesting of the local ecological resources (Alvira et al. 2015). Even in places that had been influenced by the presence of Christian missionaries, alternative beliefs that regulated human-nature interaction continued to exist. In the Güeppí inventory, for example, participants in the Secoya (or Airo-Pai) communities spoke of sacred places that were protected by mythical beings or ghost spirits (Wali et al. 2008).

Further institutional arrangements that favor sustainable natural resource management emerge from the social relations among community members. The scholarship on the commons has shown that social relationships among community members and derived social capital can facilitate the type of collective action necessary for sustainable natural resource management (Agrawal
2001). The assessments that focused on understanding social relations and community organization demonstrated the strength of customary forms of social support such as the minga, or communal work party, and other systems of reciprocity based on kinship or friendship networks. These function as social assets that increase group productivity and well-being while protecting against overexploitation of the animals and plants in the forest. Although there was variability in the strength of these social bonds, in more than $90 \%$ of the communities, kinship and reciprocal modes of exchange predominated over monetarybased transactions. For example, during the Tapiche-Blanco inventory, we noted a common pattern we had observed in almost all other inventories: regular community celebrations that fostered an environment of community participation. These community events ensured that shared community spaces were kept free of trash, weeds, snakes, and other dangerous animals. In Güeppí, Tapiche-Blanco, Ere-Campuya-Algodón, and the 
Medio Putumayo-Algodón, community members shared meat widely with neighbors after a hunt. Sharing subsistence bushmeat reduces overall hunting pressures.

Capacity for local action can also be found in fictive kinship bonds, such as compadrazgo relationships, and in more formal organizations such as churches, voluntary organizations, and even commercial ventures. For instance, the logging association in the community of Huapapa, visited during the Yaguas-Cotuhé inventory, sets harvest quotas for each resident and generates significant revenue, which is then invested in community public works. While this money is generated from logging that could be potentially harmful, the important insight is that communities are able to self-regulate the extraction of resources, and thereby minimize overexploitation (Alvira et al. 2011). These relationships, norms, and agreements are created and enforced without involving the government, which demonstrates that local forms of organization remain robust.

Finally, we found evidence that there were characteristics in the external environment that also supported sustainable natural resource management in these communities. In particular, alliances with environmental NGOs, the Peruvian National Park Service, and regional government conservation agencies have been crucial in securing support for sustainable activities. The Peruvian government has also supported sustainable timber management in some communities, such as in the Medio Putumayo-Algodón and Ere-Campuya-Algodón. On the other hand, outside actors such as logging firms, or government agencies that advance subsidies for agricultural production that threatens forests, can disrupt local practices and encourage deforestation. However, in many cases, local communities have successfully organized to resist interference from the outside, and have in fact seen protected areas as an important strategy in securing their traditional sustainable livelihoods over the long term. For example, communities in the Medio Putumayo-Algodón relayed positive experiences with protected areas. A critical part of the quality of life planning process, then, is to elevate community priorities to government agencies, NGOs, and other allies that might provide funding and technical support to implement them.

Overall, communities that reflected on their assets and values through the rapid inventory process saw explicitly how healthy natural resources are necessary for their quality of life, and often voiced support for creating protected areas near their territories. In the case of the Güeppí inventory, for example, the indigenous federations continued to work with the local office of the Peruvian National Park Service and conservation NGOs for the several years it took after the inventory to achieve protected area status. In this case, because of the strong support of the indigenous communities and the demonstrated capacity to protect the natural resource base, the Park Service and local NGOs recommended three protected areas: a national park and two indigenous communal reserves. Residents appreciated the inclusion of their concerns and the validation of their natural resource management practices and ecological knowledge through the inventories. Additionally, the rapid inventory team makes a presentation to community representatives before leaving the field, and shares the results of the biological inventory and the social inventory. Often times, community representatives expressed their pleasure at seeing themselves in the report and in learning how much their landscapes are valued by the scientists. Alternatively, as conservation NGO partners and responsible government actors learn of the rich store of ecological knowledge and local practices for sustainable resource management, they become more open to working directly with communities to develop protected area management plans. Longstanding relationships with conservation NGOs in the Putumayo watershed, for example, facilitated the development of quality of life plans in regional conservation areas, and these relationships are currently being leveraged to initiate quality of life plan development in Medio PutumayoAlgodón. In this way, communities begin to receive direct benefits from conservation efforts early in the process of protection and stewardship.

\section{Findings from quality of life plan process}

Just as community participation in the rapid inventories led to more willingness to support recommendations for the creation of protected areas, participation in the creation of quality of life plans in the 38 communities adjacent to three protected areas led to more willingness to participate in long-term protected area management and to better stewardship of natural resources in the buffer zone. Creation of the plans typically took from one year to 18 months. It entailed training community facilitators to conduct the asset mapping, multiple community visits, and stays by the Field Museum team and our Peruvian partners during which we facilitated dialogue sessions and community assemblies for each phase of the process. In all instances, once the plans were completed, we, together with our local conservation partners, began to facilitate implementation of community priorities. The process therefore enabled communities and conservation partners to address weaknesses in existing natural resource management practices, build cooperation with control and vigilance of protected areas against threats from illegal activities, and demonstrate that conservation efforts can directly benefit community quality of life.

As community residents constructed their quality of life plans, they acknowledged that although national discourses often privileged urban life and "modernity" as signs of "progress," they preferred life in their forest environments. A woman in the village of Santa Rosa de Cauchillo, visited during the Yaguas-Cotuhé inventory, noted that city life was "no good," as there they had to buy all their food and continually search for employment, which in any case did not meet their income needs (Alvira et al. 2011). With few exceptions, communities that were closest to protected areas and further from access to urban centers ranked their perception of quality of life higher than communities that were closer to roads or forests that were impacted by heavy extraction (in our sample, 52 of 75 communities were remote versus not remote). Further, as demonstrated in Fig. 3, regions that the Peruvian National Statistics Agency characterized as being in poverty or extreme poverty are places where communities we worked with ranked their quality of life as high. Thus, the planning process surfaced the disjuncture between the local values, which define well-being more holistically, and the national imaginary, which relies on only per capita income. 
Table 2. Examples of community priorities shifting to be more compatible with conservation through assets-based reflection.

\begin{tabular}{|c|c|c|c|}
\hline Geography/community & Initial priorities & New priorities after reflection & Additional conditions \\
\hline $\begin{array}{l}\text { Sierra del Divisor National } \\
\text { Park: Santa Rosa del } \\
\text { Abujao community }\end{array}$ & $\begin{array}{l}\text { Arapaima management in an oxbow } \\
\text { lake, reforestation, timber management } \\
\text { in secondary forest, collecting uña de } \\
\text { gato from the forest, } \\
\text { and raising small animals. }\end{array}$ & $\begin{array}{l}\text { Raising taricaya turtles, reforestation, } \\
\text { timber management in secondary } \\
\text { forests, } \\
\text { and artisanal crafts. }\end{array}$ & $\begin{array}{l}\text { Timber revenues should be shared with the } \\
\text { broader community. }\end{array}$ \\
\hline $\begin{array}{l}\text { Sierra del Divisor: Nuevo } \\
\text { Saposoa community }\end{array}$ & $\begin{array}{l}\text { Fish farming in constructed ponds, } \\
\text { and youth professional development. }\end{array}$ & $\begin{array}{l}\text { Arapaima fish management in natural } \\
\text { oxbow lakes, and youth training in } \\
\text { media production (videos, radio spots). }\end{array}$ & $\begin{array}{l}\text { Communal norms and regulations well } \\
\text { defined and reinforced. }\end{array}$ \\
\hline $\begin{array}{l}\text { Cordillera Azul National } \\
\text { Park: Yamino community }\end{array}$ & Logging and cattle ranching. & $\begin{array}{l}\text { Income generation through handcrafts, } \\
\text { creation of a forest conservation } \\
\text { communal reserve, and installation of } \\
\text { potable water system. }\end{array}$ & $\begin{array}{l}\text { Communal norms and regulations well } \\
\text { defined and enforced. }\end{array}$ \\
\hline $\begin{array}{l}\text { Cordillera Azul National } \\
\text { Park: } \\
\text { San Luis de Charasmana } \\
\text { community }\end{array}$ & $\begin{array}{l}\text { More intensified logging and cash } \\
\text { income through wage labor. }\end{array}$ & $\begin{array}{l}\text { Women's handcraft cooperative, } \\
\text { sustainable community forestry, and } \\
\text { wildlife conservation. }\end{array}$ & $\begin{array}{l}\text { Better cooperation with park administration } \\
\text { through participation in the voluntary park } \\
\text { guard program. }\end{array}$ \\
\hline $\begin{array}{l}\text { Ampiyacu-Apayacu: } \\
\text { Communities of Brillo } \\
\text { Nuevo and Nueva } \\
\text { Esperanza }\end{array}$ & $\begin{array}{l}\text { Fish farming in constructed ponds, } \\
\text { logging, expanding the market for } \\
\text { chambira handcrafts, and youth } \\
\text { professional development. }\end{array}$ & $\begin{array}{l}\text { Fisheries management in natural } \\
\text { oxbow lakes, integrated management of } \\
\text { chambira palm for income generation } \\
\text { through handcrafts, sustainable } \\
\text { community forestry, and youth training } \\
\text { in media production (videos and radio } \\
\text { spots). }\end{array}$ & $\begin{array}{l}\text { Timber revenues should be shared with the } \\
\text { broader community. Strong commitment to } \\
\text { protect and manage chambira palm. } \\
\text { Communal norms and regulations well } \\
\text { defined and enforced. }\end{array}$ \\
\hline
\end{tabular}

Fig. 3. Poverty as defined by the Peruvian National Statistics Agency versus local perceptions of well-being.

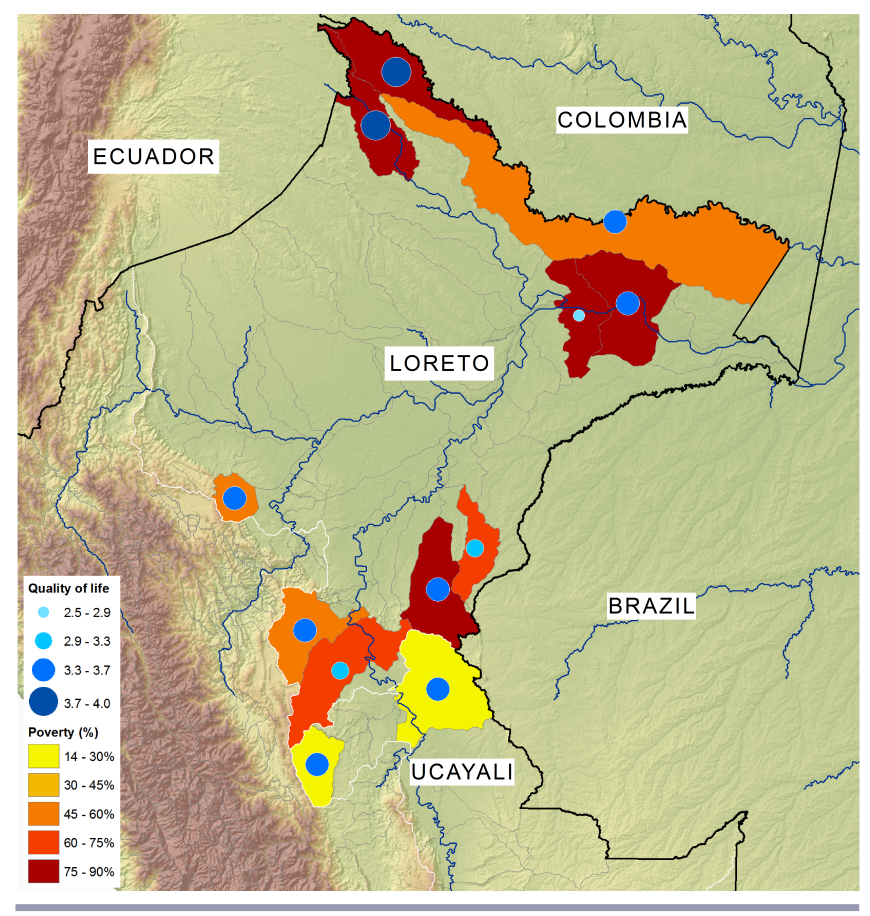

Ultimately, community residents gained confidence that their way of life, which is heavily dependent on maintaining intact forest resources, could be sustained if protected areas were established and maintained. Furthermore, the critical reflections about local values and goals involved in quality of life planning altered and clarified local peoples' identified priorities to capitalize on local assets and secure benefits from conservation. Table 2 shows how some of these priorities shifted over the course of the process. Many priorities that community members initially identified reflected traditional models of development based on information that government agencies or private firms had suggested, including cash crops, roads and infrastructure, or other priorities. After thinking carefully about the extent to which such priorities were in fact consistent with community-defined values and norms, some stated priorities were dropped or replaced, and others were expanded to include specific conditions that must be met to ensure that they align with local principles and enhance well-being.

In general, the quality of life planning process resulted in local priorities shifting to align more explicitly with conservation objectives. Table 2 delineates specific priority shifts in two communities from each of the three regions to illustrate this point.

In Santa Rosita del Abujao, for example, local people initially expressed interest in commercial arapaima management in a nearby oxbow lake. Upon closer reflection, though, they realized that they had limited knowledge of how to manage this species, and would likely deal with overexploitation by neighbors since the oxbow lake was outside their official territory. Upon considering other options, they decided to prioritize raising taricaya turtles in order to ensure the persistence of a species that they valued culturally and as a food source. In addition, they shifted away from prioritizing collecting uña de gato-a medicinally valuable nontimber forest product that can be depleted easily - toward artisanal craft projects for local women that depended on sustainable forest resources.

Building on the strengths and challenges identified in the process, community members in Nueva Esperanza, for example, decided that their priorities included technical assistance to improve 
handcraft production and access to markets (economic life) as well as increased coordination between local and municipal authorities (political life).

In Yamino, after ample reflection, the community chose to prioritize revitalizing traditional Kakataibo handcrafts, to invest in a potable water system that benefits all the households in the community, and to lobby their community to stop timber extraction and create a communal reserve in an area where they collect seeds and mahogany bark for making their handcrafts.

In the Ampiyacu-Apayacu watersheds, community members expressed interest in fish farming despite the fact that some of the families had previously experienced poor results with this activity. After reflecting on and analyzing this activity and its costs, and mapping their natural resources, they recognized the richness of the oxbow lakes and fish resources they had in their territory. Thus, they ultimately decided to manage fisheries in their oxbows at a lower cost and with greater benefits. On the other hand, women had experience harvesting chambira palm fiber to produce handcrafts for income generation and were eager to access a larger market for these products. After the women participated in an analysis of the production to market chain, they agreed that is was necessary to include integrated management of chambira palm, good processing of the fiber after harvest, managing finances, controlling quality, and reinvesting in the sustainable business. To facilitate improved operations for the handcraft production, we developed a training process and materials that facilitated the new approach to planning and execution.

Overall, because their planning process started from a consideration of strengths (assets) rather than deficits, community residents chose to prioritize a more balanced mix of actions that emphasized protecting natural resources and reinforcing cultural identity instead of conventional incomegenerating activities. In all the communities that completed the quality of life plan process in the three regions discussed here, villagers chose to prioritize initiatives that were compatible with protecting healthy forest ecosystems. The reflection on the value of local lifeways and the essential role that forest places play in maintaining autonomy and self-sufficiency led people to reject intensive and forest-degrading economic activities (such as largescale cattle ranching or unregulated logging) in favor of more small-scale income generation activities (such as boosting handcraft marketing, improved management of fish stocks in oxbow lakes, or small agroforestry production). Additionally, in every case, cultural revitalization and vigilance of natural resources were prioritized highly.

Another result of the quality of life plan process was a greater willingness on the part of the communities to cooperate in the stewardship of the protected area. The process itself intensifies the contact between the NGO and government agencies that manage the protected area and the adjacent communities. It entails a greater sharing of information about the management plan and how communities can participate as volunteer stewards. In the Ampiyacu-Apayacu region, the communities worked with the Loreto protected area service and their NGO partner to strengthen voluntary patrol regimens that monitor encroachment into the protected area. Additionally, communities participated in activities that were designed to build awareness of conservation.
In these regions, communities identified documenting their activities, transmitting cultural knowledge, and providing environmental education through new and dynamic technologies as an attractive priority. Through ongoing dialogue to explore ways to accomplish these goals, the research team and the participating communities identified videography training and video production as a suitable approach. To facilitate this, we partnered with Fernando Valdivia, a well-known documentary filmmaker, and local Shipibo videographer Ronald Su'rez to develop a training program for youth and young adults, called "Cameras in the Environment." In this program, we held a series of workshops in seven communities (four in Ampiyacu-Apayacu and three in Sierra del Divisor) to teach community members how to make documentaries and radio spots. Trainees were given video equipment and they developed their own scripts, acted, and produced short documentaries over a period of seven months. In each case, they crafted a conservation message that highlighted their community values and the importance of safeguarding the forest (The Field Museum, date unknown $b$ ). The video equipment remained with the communities, and community members have access to video editing equipment with a partner organization.

\section{DISCUSSION}

Our participatory research and community-based initiatives demonstrate that Amazonian peoples are rich in social and ecological assets and that their local cultural practices and systems of knowledge, if validated and reinforced, can contribute to the creation of protected areas and their long-term management. This approach, which is built on and sustaining existing subsistenceoriented livelihoods, is in contrast to the more conventional "integrated conservation and development" approach, which assumes that well-being will depend on providing more access to market resources (cash). A wealth of examples has demonstrated that the conventional approach largely fails to deliver the benefits of conservation, and people, frustrated by lack of improvement in their quality of life, continue to undermine conservation efforts (Brosius et al. 1998, Hughes and Flintan 2001, CIFOR 2007, but see Kilbane Gockel and Gray 2009 for a counter example).

Our approach, which emphasizes engaging forest dwellers adjacent to protected areas on their own terms, is additionally reinforced by the results of the biological inventories and the ongoing monitoring of protected areas after their creation. For example, in Güeppí, along the trail to the community of Tres Fronteras, team biologists found evidence of hunting, such as empty shotgun cartridges, but also abundant populations of certain species, such as red howler monkeys (Alouatta seniculus) and white-lipped pecaries (Tayassu pecari). Even though the abundance of certain species (such as brown woolley monkeys [ $L$. lagothricha]) was less than that in sites without hunting, these species were still somewhat curious of observers, not fearful. This indicates that hunting at these sites is likely done for subsistence rather than commercial purposes, and thereby avoids extreme exploitation (Alverson et al. 2008).

Other positive biological indicators, which suggest the use of sustainable hunting practices and the high quality of aquatic resources, were the presence of giant river otter (Pteronura brasiliensis) and Amazonian manatees (Trichechus inunguis) in Güeppí and in an inventory conducted in the Ere-CampuyaAlgodón and Yaguas-Cotuhé watersheds (Pitman et al. 2011, 
2013 ). The presence of these species reflects the ongoing recovery of populations that were hunted unsustainably for oil and meat in past decades, trends that were corroborated by the social team's interviews in local communities. Traditional subsistence hunting has not severely depleted mammal communities, in part due to the low population density of people in the region. However, some residents mentioned that in recent years, demand for bushmeat and hides has increased, especially among traders who visit the area from outside, and that this increasing demand helped spark the conservation initiatives that are being implemented in some communities. The presence of well-preserved mammal populations and the interest of local residents in maintaining them and their habitat as a source of food and other subsistence resources represent an opportunity for strengthening new community-led initiatives to protect natural resources.

Given the links between conservation and the practices and values of Amazonian communities, we posit that the assets-based approach to environmental conservation and human well-being that operates within a biocultural framework leads to more effective strategies for sustainable and adaptive management of natural resources by communities in regions adjacent to protected areas. While currently the biocultural framework is leading to exciting new ways to develop indicators of sustainability, community resilience, and biodiversity conservation (Tanguay 2015, Sterling et. al. in press), we suggest that this framework can also guide programs for empowering communities to attain a greater degree of self-sufficiency and true dignity that comes from valorization of localized cultural practices and worldviews.

Indeed, our work across the Amazon has revealed that indigenous communities today have a strong preference for paths to development that are based on an understanding and appreciation of their natural resources and culture. Recently, for example, the Inter-Ethnic Association for the Development of the Amazon in Peru-the organization that represents the majority of distinct indigenous groups in Peru's Amazon region -adopted guidelines for developing "life plans" that were first developed by its regional base organization, the Regional Organization for the Amazon in Ucayali (ORAU). ORAU's guidelines were based largely on the Field Museum's quality of life plan process and clearly call for including indigenous worldviews and modes of practice in both conservation and community improvement initiatives.

\section{CONCLUSION}

By adopting assets-based or biocultural approaches to planning, conservation, and development that are built around local strengths and norms, conservation outcomes that support wellbeing can be achieved. As moneys for conservation flow from the north to the south, it is ever more important to plan how these resources will be deployed in locally sensitive ways. For example, funds that are ostensibly aimed at reducing deforestation must also support local peoples' well-being if the program is to succeed. Beyond just delivering funds to local people, though, project implementers must ensure that local assets and traditional practices that have supported conservation in the past are bolstered, and not eroded, by funds and monetary incentives. Instead of assuming that all communities need the same types of "benefits" (e.g., better infrastructure, access to markets), the process for engagement in avoided deforestation would begin with listening to local voices and including their distinct perspectives in collaborative efforts.

In conclusion, further research needs to be done on the long-term effect of such strategies. Research should also be conducted on comparing different approaches to participatory conservation strategies. Different methods for creating and implementing quality of life plans may have different conservation or resource management outcomes. Comparative work with similar approaches in other Amazonian countries should also be carried out to mount a more comprehensive database of best practices.

Responses to this article can be read online at: http://www.ecologyandsociety.org/issues/responses. $\mathrm{php} / 9598$

\section{Acknowledgments:}

We would like to thank our local collaborators in Peru, including the numerous partners who have participated in the Rapid Inventories and the Conservation for Well-Being program. We would especially like to acknowledge CIMA-Cordillera Azul, el Instituto del Bien Común, SERNANP (Servicio Nacional de Areas Protegidas por el Estado), GOREL-Gobierno Regional de Loreto, and FENACOCA (Federación de Comunidades Nativas Cacataibo), and Jon Markel, GIS specialist at The Field Museum until 2017, who created the maps in this article. Other Field Museum colleagues whose insights, editing, and leadership have been instrumental are Debra Moskovits, Corine Vriesendorp, and Nigel Pitman. We received support from the Gordon and Betty Moore Foundation, The John D. and Catherine T. MacArthur Foundation, Blue Moon Foundation, anonymous funder, Nancy Hamill Winter Foundation, and The Field Museum. Finally, we would like to thank the anonymous reviewers and the special issue editors for their constructive and helpful comments during the review process.

\section{LITERATURE CITED}

Agrawal, A. 2001. Common property institutions and sustainable governance of resources. World Development 29(10):1649-1672. http://dx.doi.org/10.1016/S0305-750X(01)00063-8

Agrawal, A., and A. Chhatre. 2006. Explaining success on the commons: community forest governance in the Indian Himalaya. World Development 34(1):149-166. http://dx.doi.org/10.1016/j. worlddev.2005.07.013

Alverson, W., C. Vriesendorp, A. del Campo, D. Moskovits, D. Stotz, M. GarcÍa Donayre, and L. Borbor. 2008. Ecuador, Perú: Cuyabeno-GüeppÍ. Rapid Biological and Social Inventories Report 20. The Field Museum, Chicago, Illinois, USA.

Alvira, D., L. Cardoso, J. Inga Pinedo, A. López, C. Núñez Pérez, J. Paitan Cano, M. Pariona Fonseca, D. Rivera Gonz'lez, J. Urrestty Aspajo, and R. Villanueva Fajardo. 2015. Uso de recursos naturales, economÍa y conocimiento ecológico tradicional/Natural resource use, economy, and traditional ecological knowledge. Pages 165-183, 341-356, 486-493 in N. Pitman, C. Vriesendorp, L. Rivera Ch'vez, T. Wachter, D. Alvira Reyes, Á. del Campo, G. Gagliardi-Urrutia, D. Rivera Gonz'lez, 
L. Trevejo, D. Rivera Gonz'lez, and S. Heilpern, editors. Perú: Tapiche-Blanco. Rapid Biological and Social Inventories Report 27. The Field Museum, Chicago, Illinois, USA.

Alvira, D., F. Ferreyra Vela, E. Machacuri Noteno, M. Pariona Fonseca, A. Ravikumar, B. RodrÍguez Gr'ndez, A. S'enz RodrÍguez, A. Salazar Molano, M. S'nchez, and M. Valencia Guevara. 2016. Comunidades visitadas: fortalezas sociales y culturales y calidad de vida. Pages 82-98 in N. Pitman, A. Bravo, S. Claramunt, C. Vriesendorp, A. Ravikumar, D. Alvira Reyes, D. F. Stotz, T. Wachter, S. Heilpern, Á del Campo, R. C. Smith, A. R. S'enz RodrÍguez, and B. RodrÍguez Gr'ndez, editors. 2016. Perú: Medio Putumayo-Algodón. Rapid Biological and Social Inventories Report 28. The Field Museum, Chicago, Illinois, USA.

Alvira, D., J. Homan, D. Huayunga, J. Inga, A. Lancha Pizango, A. Napo, M. Pariona, P. Ruiz Ojanama, and B. Tapayuri. 2014. Comunidades humanas visitadas: Patrimonio social y cultural/ Communities visited: social and cultural assets. Pages 175-187, 363-374, 518-521 in N. Pitman, C. Vriesendorp, D. Alvira, J. A. Markel, M. Johnston, E. Ruelas Inzunza, A. Lancha Pizango, G. Sarmiento Valenzuela, P. Álvarez-Loayza, J. Homan, T. Wachter, Á. del Campo, D. F. Stotz, and S. Heilpern, editors. Perú: Cordillera Escalera-Loreto. Rapid Biological and Social Inventories Report 26. The Field Museum, Chicago, Illinois, USA.

Alvira, D., M. Pariona, R. Pinedo MarÍn, M. RamÍrez Santana, and A. S'enz. 2011. Comunidades humanas visitadas: Fortalezas sociales y culturales y uso de recursos/Communities visited: Social and cultural assets and resource use. Pages 134-154, 252-271, and 362-367 in N. Pitman, C. Vriesendorp, D. K. Moskovits, R. von May, D. Alvira, T. Wachter, D. F. Stotz, and Á. del Campo, editors. Perú: Yaguas-Cotuhé. Rapid Biological and Social Inventories Report 23. The Field Museum, Chicago, Illinois, USA.

Belaunde, L. 2010. Vivir Bien: el va y ven de nuestras dificultades en comprender los conceptos indÍgenas. Society for Applied Anthropology, Merida, Mexico.

Brosius, J. P., A. L. Tsing, and C. Zerner. 1998. Representing communities: histories and politics of community-based natural resource management. Society \& Natural Resources 11:157-168. http://dx.doi.org/10.1080/08941929809381069

Center for International Forestry Research (CIFOR). 2007. Building on success: CIFOR Annual Report 2006. Bogor, Indonesia.

Cernea, M. M., and K. Schmidt-Soltau. 2006. Poverty risks and national parks: policy issues in conservation and resettlement. World Development 34(10):1808-1830. http://dx.doi.org/10.1016/ j.worlddev.2006.02.008

Chambers, R. 1994. Participatory rural appraisal (PRA): analysis of experience. World Development 22(9):1253-1268. http://dx.doi. org/10.1016/0305-750X(94)90003-5

Chapin, M. 2004. A challenge to conservationists. World Watch 7(6).

Chapin, M., Z. Lamb, and B. Threlkeld. 2005. Mapping indigenous lands. Annual Review of Anthropology 34:619-638.
Chapin, M., and B. Threlkeld. 2001. Indigenous landscapes: a study in ethnocartography. Center for the Support of Native Lands, Arlington, Virginia, USA.

Chirif, A. 2007. Sistematización del proceso de ejecución de los proyectos de Reunificación, Revaloración Cultural y Continuidad del Pueblo Secoya. Report to IBIS. IBIS, Lima, Perú.

Colchester, M. 2009. Forest peoples, customary use and state forests: the case for reform. Forest People's Programme, Oxford, UK.

de la Cadena, M. 2010. Indigenous cosmopolitics in the Andes: conceptual reflections beyond "politics". Cultural Anthropology 25(2):334-370. http://dx.doi.org/10.1111/j.1548-1360.2010.01061. $\underline{\mathrm{X}}$

del Campo, H., and A. Wali. 2007. Applying asset mapping to protected area management in the Cordillera Azul National Park, Peru. Ethnobotany Research and Applications 5:25-36. http://dx. doi.org/10.17348/era.5.0.25-36

Dietz, T., E. Ostrom, and P. C. Stern. 2003. The struggle to govern the commons. Science 302(5652):1907-1912. http://dx.doi. org/10.1126/science.1091015

Dodge, R., A. P. Daly, J. Huyton, and L. D. Sanders. 2012. The challenge of defining wellbeing. International Journal of Wellbeing 2(3):222-235. http://dx.doi.org/10.5502/ijw.v2i3.4

Gow, P. 1991. Husband and wife, of mixed blood: kinship and history in Peruvian Amazon. Oxford University Press, Oxford, UK.

Graeber, D. 2011. Debt-the first 5000 years. Melville House, Brooklyn, New York, USA.

Hughes, R., and F. Flintan. 2001. Integrating conservation and development experience: a review and bibliography of the ICDP literature. International Institute for Environment and Development, London, UK.

Kilbane Gockel, C., and L. C. Gray. 2009. Integrating conservation and development in the Peruvian Amazon. Ecology and Society 14(2):11. http://dx.doi.org/10.5751/ES-02992-140211

La Placa, V., A. McNaught, and A. Knight. 2013. Discourse on wellbeing in research and practice. International Journal of Wellbeing 3(1):116-125. http://dx.doi.org/10.5502/ijw.v3i1.7

Leisher, C., L. H. Samberg, P. Van Buekering, and M. Sanjayan. 2013. Focal areas for measuring the human well-being impacts of a conservation initiative. Sustainability 5(3):997-1010. http://dx. doi.org/10.3390/su5030997

Maffi, L. 2001. Introduction: on the interdependence of biological and cultural diversity. In L. Maffi, editor. On biocultural diversity: linking language, knowledge, and the environment. Smithsonian Institution Press, Washington, D.C., USA.

McKnight, J., and J. Kretzmann. 1993. Building communities from the inside out: a path toward finding and mobilizing a community's assets. ACTA Publications, Chicago, Illinois, USA.

Ostrom, E. 2015. Governing the commons. Cambridge University Press, Cambridge, Massachusetts, USA. 
Ostrom, E., J. Burger, C. B. Field, R. B. Norgaard, and D. Policansky. 1999. Revisiting the commons: local lessons, global challenges. Science 284(5412):278-282. http://dx.doi.org/10.1126/ science.284.5412.278

Otto, J., C. Zerner, J. Robinson, R. Donovan, M. Lavelle, R. Villarreal, N. Salafsky, J. Alcorn, F. Seymour, C. Kleyneyer, and M. Pearl. 2013. Natural connections: perspectives in communitybased conservation. Island Press, Washington, D.C., USA.

Pitman, N., A. Bravo., S. Claramunt, C. Vriesendorp, A. Ravikumar, D. Alvira Reyes, D. F. Stotz, T. Wachter, S. Heilpern, Á. del Campo, R. C. Smith, A. R. S'enz RodrÍguez, and B. RodrÍguez Gr'ndez, editors. 2016. Perú: Medio PutumayoAlgodón. Rapid Biological and Social Inventories Report 28. The Field Museum, Chicago, Illinois, USA.

Pitman, N., E. Ruelas Inzunza, C. Vriesendorp, D. Stotz, T. Wachter, Á. del Campo, D. Alvira, B. RodrÍguez Gr'ndez, R. Smith, A, S'enz RodrÍguez, and P. Soria Ruiz. editors. 2013. Perú: Ere-Campuya-Algodón. Rapid Biological and Social Inventories Report 25. The Field Museum, Chicago, Illinois, USA.

Pitman, N., C. Vriesendorp, D. Alvira, J. Markel, M. Johnston, E. Ruelas Inzunza, A. Lancha Pizango, G. Sarmiento, P. Valenzuela, P. Álvarez-Loayza, J. Homan, T. Wachter, Á. del Campo, D. Stotz, and S. Heilpern S., editors. 2014. Perú: Cordillera Escalera-Loreto. Rapid Biological and Social Inventories Report 26. The Field Museum, Chicago, Illinois, USA.

Pitman, N., C. Vriesendorp, D. Moskovits, R. von May, D. Alvira, T. Wachter, D. Stotz, and Á. del Campo, editors. 2011. Perú: Yaguas-Cotuhé. Rapid Biological and Social Inventories Report 23. The Field Museum, Chicago, Illinois, USA.

Pitman, N., C. Vriesendorp, L. Rivera Ch'vez, T. Wachter, D. Alvira Reyes, Á. del Campo, G. Gagliardi-Urrutia, D. Rivera Gonz'lez, L. Trevejo, D. Rivera Gonz'lez, and S. Heilpern, editors. 2015. Perú: Tapiche-Blanco. Rapid Biological and Social Inventories Report 27. The Field Museum, Chicago, Illinois, USA.

Sayer, J., and B. Campbell. 2005. The science of sustainable development: local livelihoods and the global environment. Cambridge University Press, Cambridge, UK. http://dx.doi. org/10.1017/CBO9780511754968

Schlager, E., and E. Ostrom. 1992. Property-rights regimes and natural resources: a conceptual analysis. Land Economics 68 (3):249-262. http://dx.doi.org/10.2307/3146375

Selaya, G., D. Alvira, M. Medina, M. E. Molano, M. Pariona, B. RodrÍguez, A. R. S'enz, and A. Wali. 2013. Uso de recursos naturales, conocimiento ecológico tradicional y calidad de vida/ Natural resource use, traditional ecological knowledge, and quality of life. Pages 137-153, 279-293, 380-391 in N. Pitman, E. Ruelas Inzunza, C. Vriesendorp, D. F. Stotz, T. Wachter, Á. del Campo, D. Alvira, B. RodrÍguez Gr'ndez, R. C. Smith, A. R. S'enz RodrÍguez, and P. Soria Ruiz, editors. Perú: Ere-CampuyaAlgodón. Rapid Biological and Social Inventories Report 25. The Field Museum, Chicago, Illinois, USA.

Sheil, D., R. Puri, M. Wan, I. Basuki, M. V. Heist, N. Liswanti, I. Rachmatika, and I. Samsoedin. 2006. Recognizing local people's priorities for tropical forest biodiversity. Ambio 35:1724. http://dx.doi.org/10.1579/0044-7447-35.1.17

Stepp, J. R., S. Cervone, H. Castaneda, A. Lasseter, G. Stocks, and Y. Gichon. 2004. Development of a GIS for global biocultural diversity. Policy Matters 13:267-270.

Sterling, E., T. Ticktin, K. Morgan, G. Cullman, D. Alvira, P. Andrade, N. Bergamini, E. Betley, K. Burrows, S. Caillon, J. Claudet, R. Dacks, P. Eyzaguirre, C. Filardi, N. Gazit, C. Giardina, S. Jupiter, K. Kinney, J. McCarter, M. Mejia, K. Morishige, J. Newell, L. Noori, J. Parks, P. Pascua, A. Ravikumar, J. Tanguay, A. Sigouin, T. Stege, M. Stege, and A. Wali. 2017. How do we build culturally grounded indicators of resilience and adaptation and scale them from local to global? Environment and Society: Advances in Research, in press.

Stiglitz, J., A. Sen, and J. Fitoussi. 2010. Report by the Commission on the Measurement of Economic Performance and Social Progress. Commission on the Measurement of Economic Performance and Social Progress, Paris, France.

Tanguay, J. 2015. Alternative indicators of wellbeing for Melanesia: cultural values driving public policy. Pages 162-172 in L. MacDowall, M. Badham, E. Blomkamp, and K. Dunphy, editors. Making culture count: the politics of cultural measurement. Palgrave Macmillan, Basingstoke, UK. http://dx.doi. org/10.1007/978-1-137-46458-3_11

The Field Museum. date unknown $a$. Conservation for well-being: tools. http://conservationforwellbeing.fieldmuseum.org/tools/

The Field Museum. date unknown $b$. Conservation for well-being: success stories. http://conservationforwellbeing.fieldmuseum. org/success-stories/

The Field Museum. 2011. Rapid inventories. https://www. fieldmuseum.org/science/blog/rapid-inventories

The Field Museum. 2016a. Rapid biological inventories. http:// fm2.fieldmuseum.org/rbi/

The Field Museum. 2016b. Conservation for well being: home. http://conservationforwellbeing.fieldmuseum.org/

Vel'squez Landmann, E., and M. Macedo Bravo. 2016. Plan de Vida. GuÍa para la Planificacción Colectiva. Ministerio de Cultura, San Borja, Lima, Peru. http://centroderecursos.cultura. pe/sites/default/files/rb/pdf/Plan-de-vida.pdf

Viveiros de Castro, E. 1998. Cosmological deixis and Amerindian perspectivism. Journal of the Royal Anthropological Institute 4 (3):469-488. http://dx.doi.org/10.2307/3034157

Wali, A. 2012. A different measure of well-being. American Anthropologist 114(1):16-18.

Wali, A. 2016. Contextualizing the collection: environmental conservation and quality of life in the buffer zone of the Cordillera Azul National Park. In A. Wali and C. Odland, editors. The Shipibo-Conibo: culture and collections in context. The Field Museum, Chicago, Illinois, USA.

Wali, A., G. Darlow, C. Fialkowski, M. Tudor, H. del Campo, and D. Stotz. 2003. New methodologies for interdisciplinary research and action in an urban ecosystem in Chicago. Conservation Ecology 7(3):2. http://dx.doi.org/10.5751/ES-00568-070302 
Wali, A., M. Pariona, T. Torres, D. RamÍrez, and A. Sandoval. 2008. Comunidades humanas visitadas: fortalezas sociales y uso de recursos/Human communities visited: social assets and use of resources. Pages 111-121, 234-245, 362-365 in W. S. Alverson, C. Vriesendorp, Á. del Campo, D. K. Moskovits, D. F. Stotz, M. GarcÍa Donayre, and L. A. Borbor, editors. Ecuador, Perú: Cuyabeno-GüeppÍ. Rapid Biological and Social Inventories Report 20. The Field Museum, Chicago, Illinois, USA.

West, P., and D. Brockington. 2006. An anthropological perspective on some unexpected consequences of protected areas. Conservation Biology 20(3):609-616. http://dx.doi.org/10.1111/ j.1523-1739.2006.00432.x

Wolf, E. R. 1982. Europe and the people without history. University of California Press, Berkeley, California, USA. 